\title{
The Effect of Inflation, Rupiah Exchange Rate, Interest Rate, Money Supply, Industry Production Index, Dow Jones Islamic Market Index in Malaysia and Japan on ISSI
}

\author{
Rizki Nur Ariyanti Gunawan ${ }^{1}$, and Anton Bawono ${ }^{1 *}$ \\ ${ }^{1}$ Faculty of Islamic Economics and Business, IAIN Salatiga, Indonesia
}

\begin{abstract}
The purpose of this study is to determine the effect of inflation, rupiah exchange rate, interest rate, money supply, industry production index, Dow Jones Islamic Market Index Malaysia and Japan on ISSI. This research used secondary time series data which is accessed from the official website of ISSI. The sampling technique used a saturated sample with 62 observations. The research method uses descriptive statistics and multiple linear regression analysis. The results show that inflation has a negative but not significant effect on ISSI. The Rupiah exchange rate, interest rate, and DJIJP have a negative and significant effect on ISSI. The money supply, industrial production index, and DJMY25D have a positive and significant effect on ISSI.
\end{abstract}

\section{Introduction}

Many countries are looking forward to the economic development of a country by looking at the development and existence of the country's capital market. This is because the capital market has an important role in the economy-because, with stock investments, companies can immediately use these funds to expand their business, so that companies can improve their performance. Where the performance and productivity of good companies reflect the good economic conditions of the country (Kurniawan, 2021).

Indonesia has a great opportunity to develop the Islamic capital market, especially in the field of Islamic stocks, because the majority of the population is Muslim. Based on Otoritas Jasa Keuangan (OJK) data, there have been two Sharia stock indices that have developed quite significantly. One of them is the Indonesian Sharia Stock Index (ISSI), ISSI itself is a Sharia stock index that is listed on the IDX and passed, and-included in the Sharia Securities List (DES) issued by the OJK. The listed issuers must go through a selection process carried out twice a year to remain based on Sharia principles. So, at the end of the selection, there are always issuers that enter and leave the ISSI constituents (Berutu, 2020). Which since its issuance on May 12, 2011 to February 2020 has grown by 46.13 percent.

However, in its development, many factors influence the ISSI movement. According to Rachmawati \& Nisful (2015), ISSI can be influenced by macroeconomic factors. Meanwhile,

* Corresponding author: antonbawono@iainsalatiga.ac.id 


\section{$A \mathrm{C} \overline{I E B}$ Annual International Conference \\ on Islamic Economics and Business, 2021}

according to Widowati (2018), ISSI can be influenced by the international world, such as world oil and gold prices, and international stock indexes.

Based on the explanation above, the researcher wants to do further research to analyze the effect of the above variables (inflation, rupiah exchange rate, interest rate, money supply, Indonesian Production Index, Dow Jones Islamic Market Index in Malaysia and Japan on ISSI.

\section{Literature Review}

\subsection{Portofolio Theory}

Modern portfolio theory is based on the view that all investors avoid risk. In portfolio theory, risk is the consequence of a mismatch in the desired profit. Risk arises because the timing and amount of rewards that investors will get is uncertain. So, in this theory, the method of combining several stocks into a portfolio is taught or commonly called stock diversification, so that the risks obtained can be minimized and the profits obtained can be maximized. A portfolio is a combination of financial assets in one unit managed by an investor, investment company, or financial institution (Pratiwi et al., 2014).

\subsection{Indonesia Sharia Stock Index (ISSI)}

The Indonesian Sharia Stock Index (ISSI) is all shares listed on the IDX and passed the DES issued by the OJK. The base year for ISSI is May 12, 2011. Issuers who are members of ISSI are reviewed twice a year by following the examination agenda of the DES. Therefore, every selection period there are issuers that leave and enter ISSI constituents. ISSI uses the method that has been determined by the IDX, namely by using the weighted average of ISSI's capitalization with December 2007 as the base year of calculation (Berutu, 2020).

\subsection{Inflation}

Inflation is an event of rising prices for goods and services prevailing in the economy (Sukirno, 2012). Inflation can be said if price increases are general and occur in various regions within a country. An increase in inflation could harm various sectors of the economy.

\subsection{Rupiah Exchange Rate (RER)}

The rupiah exchange rate is a record of market prices from foreign currencies to the rupiah. In other words, the rupiah exchange rate describes the level of exchange rates from foreign currencies to the rupiah. International transactions use exchange rates (Adiwarman, 2015).

\subsection{Interest Rate (IR)}

The interest rate is the price of using investment funds (Boediono, 2014). Interest rates for the government are policy indicators to maintain the country's economic stability. However, for the company, the interest rate are an additional burden for the company for the credit taken by the company, and this increase will later have an impact on stock prices. In addition, an increase in interest rates could also divert investors' interest from investing in other sectors that are considered more profitable than stock investments (Sunariyah, 2013). 


\section{$A T \overline{I E B}$ Annual International Conference \\ on Islamic Economics and Business, 2021}

\subsection{Money Supply}

Money supply in a broad sense is divided into two, namely M1 (currency and demand deposits) and M2 (M1 + quasi money + securities other than shares with a remaining term of one year). Therefore, many countries use M2 as the amount of money circulating in their country (Pangaribuan, 2018).

\subsection{Industry Production Index (IPI)}

The IPI value is a scale of output from the production sector, hence it is close to real GDP (Umam et al., 2019). Therefore, the IPI value can describe the economic condition of a country and can also replace monthly GDP due to the unavailability of monthly GDP data (Purnamasari \& Sukmana, 2017).

\subsection{Dow Jones Islamic Market Index (DJIMI)}

The Dow Jones Islamic Market Index (DJIMI) is a Sharia stock index published in Bahrain in February 1999 and is part of the Dow Jones Global Index (DJGI). DJIMI is growing in various countries, both countries with a Muslim majority and minority countries. Although under DJGI, issuers that enter DJIMI are selected based on Sharia principles. Therefore, DJIMI shares are the basis for investors' considerations before making a decision (Beik \& Fatmawati, 2014).

\subsection{Inflation and ISSI}

The movement of inflation can affect the development of ISSI. A rise in inflation can reduce people's purchasing power and the value of money. That can make the company's profits fall and have an impact on reducing the dividends received so that it can suppress stock prices (Aji \& Mukri, 2020). In line with Suciningtias \& Khoiroh (2015) which state that inflation has a negative and significant effect on ISSI.

\subsection{Rupiah Exchange Rate (RER) and ISSI}

The depreciation of the rupiah exchange rate can increase the company's production costs and ultimately make an impact on the decline in company profits and dividends earned by investors. So that many investors release their shares, and this result in a declining stock price (Suciningtias \& Khoiroh 2015). In line with Widyasa \& Worokinasih (2018) which revealed that the rupiah exchange rate had a negative and significant effect on ISSI.

\subsection{Interest Rate (IR) and ISSI}

The movement of interest rates is inversely proportional to ISSI because interest rates are the cost of using funds for investment (Boediono 2014). An increase in interest rates could increase the company's costs so that the profits obtained are reduced and will have an impact on decreasing dividends and stock prices. In addition, it can also divert investors' interests from investing their capital in other investments whose profits are greater than stock investments. In line with Widyasa \& Worokinasih (2018) which revealed that interest rates have a negative and significant effect on ISSI. 


\section{$A \mathrm{C} \overline{I E B}$ Annual International Conference \\ on Islamic Economics and Business, 2021}

\subsection{Money Supply and ISSI}

The increase in money supply could increase people's purchasing power so that company profits and dividends received by investors will increase and will have an impact on rising stock prices. In line with research conducted by Chotib \& Huda (2019) which stated that money supply had a positive and significant effect on ISSI.

\subsection{Industry Production Index (IPI) and ISSI}

The increase in IPI illustrates that the economy is improving, the production sector is abundant and the company's condition is good (in this case, profit). This condition will attract investors to invest their capital in stock investments, to increase stock prices. This is in line with Umam et al. (2019) which revealed that IPI had a positive and significant effect on ISSI.

\subsection{Dow Jones Islamic Market Index Malaysia (DJMY25D) and ISSI}

ISSI can also be influenced by the international community, such as the shares of DJMY25D. According to Climent and Meneu in Puspitasari et al. (2015), stock exchanges are still in the same region will have the same movement because they are integrated. The mutual integration of stock exchanges will have an impact on the country's economy because investors can invest in shares in countries whose stock exchanges have been integrated. This makes the company have additional capital so that it can expand its business. This is in line with Kurniawan et al. (2019) swhich stated that DJMY25D had a positive and significant effect on ISSI.

\subsection{Dow Jones Islamic Market Index Japan (DJIJP) and ISSI}

The movement of DJIJP is inversely proportional to ISSI, because long-term investment in developed countries is not profitable, although in terms of high economic value, the rate of economic growth is not too large. The rate of economic growth is a concern for investors in making decisions because the rate of economic growth can detect how companies are developing in the country. Companies located in countries with fast-growing economic growth will benefit investors who invest long-term. According to Beik \& Fatmawati (2014), DJIJP has a negative and significant effect on JII.

Hence, the following hypotheses have been generated for the paper after going through the literature:

Null Hypothesis 1(H1): Inflation has no effect on ISSI.

Null Hypothesis 2 (H2): The Rupiah exchange rate has no effect on ISSI.

Null Hypothesis 3 (H3): Interest rates have no effect on ISSI.

Null Hypothesis 4 (H4): Money supply has no effect on ISSI.

Null Hypothesis 5 (H5): IPI has no effect on ISSI.

Null Hypothesis 6 (H6): DJMY25D has no effect on ISSI.

Null Hypothesis 7 (H7): DJIJP has no effect on ISSI.

\section{Method}

The research is a quantitative research using multiple linear regression analysis method. The variables used are ISSI as the dependent variable, while inflation, rupiah exchange rate, interest rates, money supply, industrial production index, Dow Jones Islamic Market Index 


\section{$A \mathrm{C} \overline{I E B}$ Annual International Conference \\ on Islamic Economics and Business, 2021}

Malaysia and Japan as independent variables. The data used are secondary time series data sourced from the official website which is accessed through www.bi.go.id, www.bps.go.id, www.ojk.go.id, and other institutions that provide statistical data. The population for the study is considered monthly data from January 2015 to February 2020, covering 62 observational data. While sampling uses a saturated sample technique, namely by using all the data in the population as a sample. The data was then tested with Eviews 9 version.

\section{Result and Discussion}

Table 1. Regression Test Results

\begin{tabular}{ccccc}
\hline \hline Variable & Coefficient & Std. Error & t-Statistic & Prob. \\
\hline \hline C & -0.214581 & 0.259593 & -0.826606 & 0.4122 \\
D(X1(-1)) & -1.046389 & 0.540270 & -1.936789 & 0.0582 \\
D(X2(-1)) & -0.007356 & 0.001218 & -6.040906 & 0.0000 \\
D(X3(-1)) & -6.090599 & 0.946300 & -6.436222 & 0.0000 \\
D(X4(-1)) & 0.018542 & 0.004126 & 4.494066 & 0.0000 \\
D(X5(-1) & 0.316928 & 0.033732 & 9.395563 & 0.0000 \\
D(X6(-1)) & 0.092467 & 0.007661 & 12.06955 & 0.0000 \\
D(X7(-1)) & -0.016331 & 0.004162 & -3.924126 & 0.0003 \\
\hline \hline
\end{tabular}

$\mathrm{Y}=\mathbf{- 0 . 2 1 4 6}-1.0464 X_{1}-0.0074 X_{2}-6.0906 X_{3}+\mathbf{0 . 0 1 8 5} X_{4}+0.3169 X_{5}+\mathbf{0 . 0 9 2 5} X_{6}-0.0163 X_{7}$

$+\mathbf{e}$

Where,

Y : ISSI

$\mathrm{X}_{1}$ : Inflation

$\mathrm{X}_{2}$ : Rupiah Exchange Rate

$\mathrm{X}_{3}$ : Interest Rate

$\mathrm{X}_{4} \quad$ : Money Supply

$\mathrm{X}_{5} \quad$ : Industry Production Index

$\mathrm{X}_{6} \quad$ : DJMY25D

$\mathrm{X}_{7}$ : DJIJP

e : Error

\subsection{The Effect of Inflation on ISSI}

Based on regression results, it can be seen that the coefficient is -1.0464 and the probability is $0.0582>0.05$. It can be interpreted that $\mathrm{H} 1$ is rejected or inflation has a negative but not significant effect on ISSI. This is due to the movement of inflation under the category of mild inflation or below 10 percent per year. Because it is still at a safe level, it does not affect investors in investing. Another possibility is that there are several other considerations or factors taken into account by investors when investing in Islamic stocks. (Widyasa \& Worokinasih, 2018) These results are supported by Mawarni \& Widiasmara (2018).

\subsection{The Effect of the Rupiah Exchange Rate on ISSI}

Based on regression result, it can be seen that the coefficient is -0.0073 and the probability is $0.0000<0.05$. It can be interpreted that $\mathrm{H} 2$ is accepted or the rupiah exchange rate has a negative and significant effect on ISSI. This is due to the depreciating rupiah exchange rate 


\section{$A \mathrm{C} \overline{I E B}$ Annual International Conference \\ on Islamic Economics and Business, 2021}

that reduced people's purchasing power to buy consumer goods. People would prefer to save their money rather than use it to spend it on consumer goods because the value of money is not valuable. This will have an impact on reducing the company's profit and reducing dividend income for investors. When the dividends received fall, it will result in a decrease in investor interest in investing their capital in stocks and will lower the stock price. (Mawarni \& Widiasmara, 2018) These results are in line with research conducted by Suciningtias \& Khoiroh (2015).

\subsection{The Effect of Interest Rates on ISSI}

Based on regression result, it can be seen that the coefficient is -6.0906 and the probability is $0.0000<0.05$, it can be interpreted that $\mathrm{H} 3$ is accepted or the interest rate has a negative and significant effect on ISSI. This is due to rising interest rates can increase the company's loan interest, so the company's costs will rise and will have an impact on decreasing profits received by the company. Decreased profits mean the dividends received by investors will also decrease, so investors will prefer to sell their shares and switch to other, more profitable investments. This resulted in stock prices falling-Widyasa \& Worokinasih (2018). These results are supported by Firdausi et al. (2016).

\subsection{The Influence of the Money Supply on ISSI}

Based on regression result, it can be seen that the coefficient is 0.0185 and the probability is $0.0000<0.05$, it can be interpreted that $\mathrm{H} 4$ is accepted or JUB has a positive and significant influence on ISSI. An increase in the money supply will encourage people's purchasing power. The increase in people's purchasing power can have an impact on increasing company profits. The company's profit increases, the dividend income also increases which have a positive/negative impact on rising stock prices. So that the company has additional capital to expand its business and this can improve the company's performance. Improved company performance can attract investors to invest in company shares. (Zuhri et al., 2020) These results are supported by Chotib \& Huda (2019).

\subsection{The Effect of the Industrial Production Index (IPI) on ISSI}

Based on regression result, it can be seen that the coefficient is 0.3169 with a probability is $0.0000<0.05$. It can be interpreted that H5 is accepted or IPI has a positive and significant influence on ISSI. This is due to the Industrial Production Index (IPI) is one of the parameters that describes the production conditions of a country. The improvement in IPI will have an impact on increasing industrial production and company profits. Rising company profits can increase dividends received by investors. This could encourage investors to invest their capital in stock investments. The more investors who are interested in investing their capital in stock investments, the more ISSI's stock price will rise. (Ash-Shiddiqy, 2019) These results are in line with (Firdausi et al., 2016).

\subsection{The Effect of the Dow Jones Islamic Market Index Malaysia (DJMY25D) on ISSI}

Based on regression result, it can be seen that the coefficient is 0.0925 with a probability is $0.0000<0.05$. It can be interpreted that H6 is accepted or DJMY25D has a positive and significant influence on ISSI. This is because Indonesia and Malaysia are member countries in the ASEAN region, which, according to Climent and Meneu in Puspitasari et al. (2015), 


\section{$A I C \overline{I E B}$ Annual International Conference \\ on Islamic Economics and Business, 2021}

capital markets that are still in one regional area tend to have the same movement and there is a contagion effect. This makes the relationship between the stock exchanges closer and influences each other. The integration between capital markets is very important to improve the country's economy because investors can have access to invest in stocks in all countries that are included in the capital market integration area. Besides that, the state company will also have additional capital and can expand its business sector. So, countries whose capital markets are integrated with each other will have a positive impact on market integration. These results are supported by Kurniawan et al. (2019).

\subsection{The Influence of the Japanese Dow Jones Islamic Market Index (DJIJP) on ISSI}

Based on regression result, it can be seen that the coefficient is -0.0163 with a probability is $0.0003<0.05$. It can be interpreted that $\mathrm{H} 7$ is accepted or DJIJP has a negative and significant effect on ISSI. Japan, which is one of the developed countries, is indeed one of the choices for investors to be able to invest there. However, long-term investment in developed countries is considered less profitable. This is because the economic growth of developed countries is not growing rapidly. The economic value of developed countries is indeed large, but economic growth tends to run slowly. The rate of economic growth is very important to the attention of investors because the greater the economic growth of a country, the greater the development of companies in that country, and this can benefit investors because the large returns in the long term are in fast-growing companies. These results are supported by Beik \& Fatmawati (2014).

\section{Conclusion and Suggestion}

Inflation has a negative but not significant effect on ISSI. Rupiah exchange rate, Interest rates, and DJIJP have negative and significant effect on ISSI. Meanwhile, money supply, industry production index, and DJMY25D have positive and significant effect on ISSI.

Based on the results of the research and the conclusions above, the suggestions that can be given are: this research certainly has shortcomings, so it needs improvement and further follow-up. Therefore, for further research, it is recommended to add variables that are more Sharia and related to ISSI such as SBIS. And this study only used domestic macroeconomic factors and Islamic stock indexes in Asia. It would be even better if added international macroeconomic factors and international Sharia stock indexes outside Asia so that the results obtained would have been more accurate.

\section{Research Limitations}

This research is research that uses secondary data in the form of time series. So this research has limitations, such as the availability of data on the official website that the researcher uses is incomplete because not all official websites provide monthly data and do not publish all years. These limitations make the researcher unable to indicate the true picture of the situation. In addition, the researchers also did not use all the indicators that could affect ISSI, so the research results obtained still need to be followed up to get maximum results.

\section{References}

Adiwarman, K. (2015). Macro economy Islam (5th ed.). Rajawali Press. 


\section{$A I C \quad$ Annual International Conference on Islamic Economics and Business, 2021}

Aji, A. M., \& Mukri, S. G. (2020). Monetary Strategy based on Sharia Economy (Islamic Efforts to Overcome Inflation) (revision 202). Deepublish CV Budi Utama.

Ash-Shiddiqy, M. (2019). The Effect of Industrial Production Index (IPI), Bank Indonesia Syariah Certificates (SBIS), Inflation, and Rupiah Exchange Rate on Indonesian Syariah Stock Index (2012-2018 Period). Jurnal STAIKAP Pekalongan, 3(1), 39-50.

Beik, I. S., \& Fatmawati, S. W. (2014). The Effect of International Sharia Stock Price Index and Macroeconomic Variables on the Jakarta Islamic Index. Al-Iqtishad, VI(2), 155178.

Berutu, A. G. (2020). Indonesian Islamic Capital Market Concepts and Products (F. E. Yudiana (ed.)). Lembaga Penelitian dan Pengabdian kepada Masyarakat (LP2M) IAIN Salatiga.

Boediono. (2014). Introduction to Science Synopsis Series - No. 5 Macroeconomics. BPFE.

Chotib, E., \& Huda, N. (2019). Analysis of the Effect of Macroeconomic Variables on the Indonesian Sharia Stock Index (ISSI) for the 2016-2019 Period. Journal of Economics and Bussiness Aseanomics (JEBA), ISSN 2527-7499 (Print) 2528-3634 (Online), 4(1), 1-20. http://academicjournal.yarsi.ac.id/jeba

Firdausi, A. N., Fahmi, I., \& Saptono, I. T. (2016). The Influence of the ASEAN Regional Stock Price Index and Macroeconomic Variables on the Indonesian Sharia Stock Price Index (ISSI). Al-Muzara'ah, 4(2), 76-96. https://doi.org/10.29244/jam.4.2.76-96

Kurniawan, A., Alia, F., \& Apriyani, M. (2019). Influence of Dow Jones Islamic World Malaysia Index and Dow Jones Islamic Market Index Japan on ISSI (January 2013 December 2017). Finansia : Jurnal Akuntansi Dan Perbankan Syariah, 2(1), 93-106.

Kurniawan, M. (2021). Islamic Banks and Financial Institutions. Penerbit Adab CV Adanu Abinata.

Mawarni, C. P., \& Widiasmara, A. (2018). The Effect of the FED Rate, World Oil Prices, BI Rate, Inflation and Rupiah Exchange Rate on the Indonesian Sharia Stock Index (ISSI) for the Period of 2011-2017. 2(2), 281-297.

Pangaribuan, J. (2018). Monetary Delusions Different Paradigms About Money, the Financial System, and Their Discussion. Deepublish CV Budi Utama.

Pratiwi, A. E., Dzulkirom, M., \& Azizah, D. F. (2014). Analysis of Sharia Capital Market Stock Portfolio Investment with Markowitz Model and Single Index Model. Jurnal Administrasi Bisnis, 17(1), 1-10.

Purnamasari, D., \& Sukmana, R. (2017). The Influence of World Gold Prices, World Crude Oil Prices and Industrial Production Indexes on the Stock Index in the Jakarta Islamic Index (JII) in the Long and Short Term (January 2005-December 2015 Period). Jurnal Ekonomi Syariah Teori Dan Terapan, 4(7), 515. https://doi.org/10.20473/vol4iss20177pp515-530

Puspitasari, A., Siregar, H., \& Andati, T. (2015). Asean Stock Exchange Integration Analysis 5. Jurnal Ekonomi Dan Kebijakan Pembangunan, 4(2), 187-206.

Rachmawati, M., \& Nisful, L. (2015). Macroeconomic Factors Affecting Stock Price Movements on the Indonesian Sharia Stock Index (ISSI) on the Indonesia Stock Exchange (IDX). Jurnal JESTT, 2(1), 51-72.

Suciningtias, S. A., \& Khoiroh, R. (2015). Analysis of the Impact of Macroeconomic Variables on the Indonesian Sharia Stock Index (ISSI). Jurnal UNISSULA, 2(1), 398412.

unissula.com/jurnal.unissula.ac.id/index.php/cbam/article/viewFile/323/270

http://lppm-

Sukirno, S. (2012). Macroeconomics Theory Introduction. Rajawali Press.

Sunariyah. (2013). Introduction to Capital Market Knowledge. UPP-STIM YKPN.

Umam, K. A., Ratnasari, R. T., \& Herianingrum, S. (2019). The Effect of Macroeconomic Variables in Predicting Indonesian Sharia Stock Index. Jurnal Ekonomi Dan Bisnis Islam (Journal of Islamic Economics and Business), 5(2), 223. 


\section{$A I \overline{I F B}$ Annual International Conference \\ on Islamic Economics and Business, 2021}

https://doi.org/10.20473/jebis.v5i2.15031

Widowati, N. D. (2018). Integration Analysis of the World Sharia Stock Index and Macroeconomic Variable Performance Against ISSI. Tesis Universitas Islam Indonesia, Yogyakarta.

Widyasa, V. I. A., \& Worokinasih, S. (2018). The Effect of Inflation Rate, Rupiah Exchange Rate, and Domestic Interest Rate on the Indonesian Sharia Stock Index (ISSI) (Study on Sharia Stocks Listed on the Indonesia Stock Exchange Period 2013-2017). Administrasi Bisnis (JAB)|Vol., 60(1), 119-128.

Zuhri, A., Maslichah, \& Sudaryanti, D. (2020). The Effect of Inflation, Rupiah Exchange Rate, BI Rate, and the Money Supply on the Indonesian Sharia Stock Index (ISSI) for the 2016-2018 Period. Jurnal E-JRA, 9(9), 1-13. 